\title{
Research in action: mammography utilization following breast cancer awareness campaigns in Lebanon 2002-05
}

S.M. Adib, ${ }^{1}$ M.A. Sabbah, ${ }^{1}$ S. Hlais ${ }^{1}$ and P. Hanna ${ }^{2}$

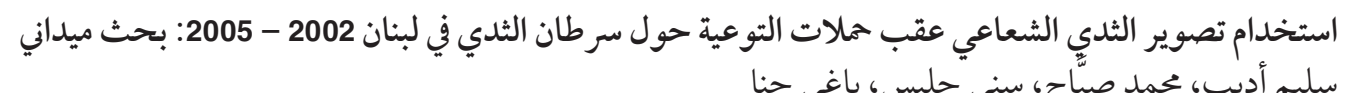

الخلاصسة: أجريَتْ في لبنان أربعة مسوحات متعاقبة شمل كل منها 1200 إمرأة في سياق الحملات الوطنية للتوعية

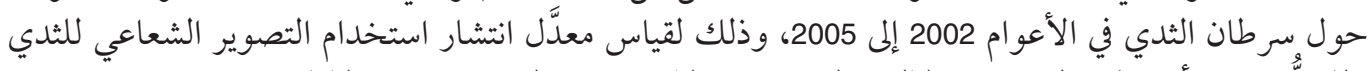

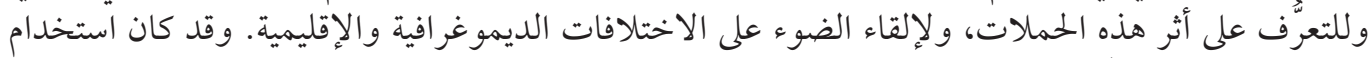

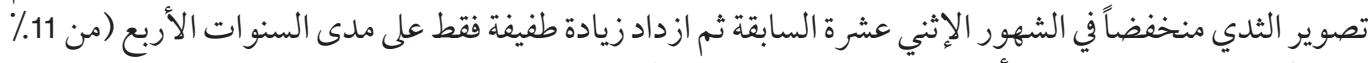

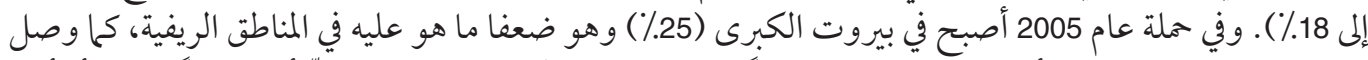

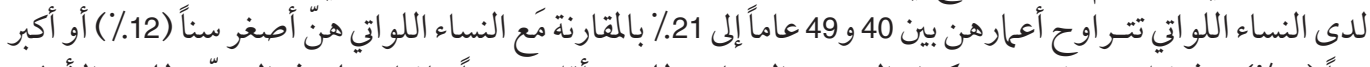

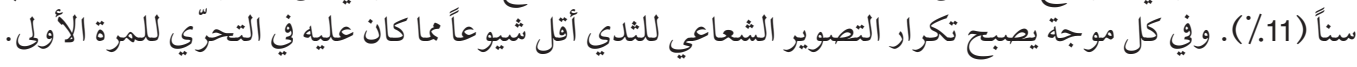

ABSTRACT Four consecutive annual surveys of 1200 women each were conducted in Lebanon in connection with the National Breast Cancer Awareness campaigns (2002-05) to measure the prevalence of mammography utilization and the impact of these campaigns, and to highlight regional and demographic differences. The utilization of mammography in the previous 12 months was low and increased only slightly over 4 years (from $11 \%$ to $18 \%$ ). In the 2005 campaign, it was twice as high (25\%) in greater Beirut than in mostly rural areas, and among women aged $40-59$ years (about $21 \%$ ) compared with younger (12\%) or older (11\%) women. In each wave, repeat mammograms were less common than first time screening.

Utilisation de la mammographie suite aux campagnes d'information sur le cancer du sein au Liban en 2002-2005 : la recherche en marche

RÉSUMÉ Quatre enquêtes annuelles consécutives ont été réalisées auprès de 1200 femmes chacune, au Liban, dans le cadre des campagnes nationales d'information sur le cancer du sein (2002-2005) afin de mesurer la prévalence de l'utilisation de la mammographie et l'impact de ces campagnes, et de mettre en lumière les différences régionales et démographiques. L'utilisation de la mammographie au cours des 12 mois précédents était faible et n'a augmenté que légèrement pendant les quatre années (de $11 \%$ à $18 \%$ ). Pendant la campagne de 2005, elle était deux fois plus élevée (25\%) dans l'agglomération de Beyrouth que dans les zones à dominante rurale, et chez les femmes âgées de 40 à 59 ans (environ $21 \%$ ) que chez les femmes plus jeunes (12\%) ou plus âgées (11\%). À chaque vague de campagne, les mammographies de contrôle étaient moins fréquentes que les premières mammographies de dépistage.

${ }^{1}$ Family Medicine Program, Faculty of Medicine, Université Saint-Joseph, Beirut, Lebanon (Correspondence to S.M.Adib: salim.adib@usj.edu.Ib).

${ }^{2}$ Ministry of Public Health, Beirut, Lebanon.

Received: 03/01/08; accepted: 27/03/08. 


\section{Introduction}

Breast cancer is the most common non-skin malignancy among women in Lebanon, as it is in the whole world. For the past 50 years, it has topped the list of cancers among women [1-3]. About 1 in every 4 cancers in Lebanon is breast cancer: age-adjusted incidence is currently estimated at 76 new cases per 100000 [4]. Because of concern about the importance of improving prognosis by diagnosing breast cancer in earlier stages, many community campaigns have emerged throughout the world with the aim of increasing uptake of screening by mammography. National levels of mammography utilization for breast cancer screening in the Lebanese population are unavailable.

In 2002, the Ministry of Public Health $(\mathrm{MOPH})$ in Lebanon started organizing annual breast cancer awareness campaigns around the time of the International Breast Cancer Month in October. MOPH has involved the private sector and various health and academic centres in planning, implementing and evaluating these awareness campaigns, which rely heavily on the media. The 2003-05 campaigns included a component to assess their impact. In this study, data obtained from these crosssectional surveys are analysed and discussed. These are the 1st multi-regional findings on breast cancer screening ever published in Lebanon. They mark a turning point in public health in the recent years to tackle the issue of cancer prevention seriously and openly, and to evaluate all public health interventions to optimize their effects.

The main objectives of this action research were: to measure the prevalence of mammography utilization among women in Lebanon; to assess the impact of campaigns in prompting women to obtain a mammography; and to highlight regional and demographic differences requiring specific approaches in future campaigns.

\section{Background to the study: the campaigns}

The central message of the breast cancer awareness campaigns was the promotion of annual mammography screenings among asymptomatic women aged 40 years or older in order to detect incident cancers at the earliest possible stage and thus to improve the prognosis. All public communications stressed that for breast cancer detected early there was a greater than $90 \%$ chance of full recovery.

Screening mammographies are rarely reimbursed by third-party payers in Lebanon, forcing physicians to declare the test for diagnostic purposes. In order to facilitate women in obtaining a mammography, MOPH negotiated a discount price of 40000 Lebanese pounds (about US\$ 27 ) or less during the campaign month with about 160 centres: hospitals, primary care centres and private laboratories. Participating centres were listed by region on pamphlets widely distributed in locations such as pharmacies, waiting rooms, salons and supermarkets. These pamphlets also included frequently asked questions and answers on breast cancer risk factors, signs, detection and prognosis.

An educational compact disk with a standard presentation was also prepared which health care providers could use for lectures and presentations in community centres and social clubs. The campaigns also included street signs, billboards and pink ribbons, television and radio advertisements and television talk shows. Starting with the 2005 campaign, cell-phone companies sent out brief advertisements free-ofcharge via messages to mobile telephones, and campaign banners were included on the homepages of the major Lebanese Internet service providers. The 2006 campaign could not be implemented as a result of the IsraelLebanon war during the summer of 2006. 
The 2003-05 campaigns included impact assessment components. In September 2003 a pre-campaign survey (S1) was conducted in 5 mostly rural areas outside greater Beirut, which included the city of Beirut and its suburbs, to assess any possible long-term effect from the October 2002 campaign. A post-2003 campaign survey was conducted in the same areas in January 2004 (S2). Two other surveys were conducted in January 2005 and 2006 (S3 and S4) to evaluate the previous year's campaigns. Since the activities of the campaigns were inevitably highly concentrated in the greater Beirut area, organizers were initially most interested in assessing the impact in relatively distant regions. Consequently, the 2002 and 2003 surveys did not include samples from greater Beirut. Later, data from the greater Beirut area were deemed equally important, if only for comparison. Thus the 2004 and 2005 surveys added samples of women from Beirut city and suburbs to those from 5 other rural districts.

\section{Methods}

\section{Study design and target population}

Cross-sectional sample surveys were conducted between 2003 and 2005 targeting adult women selected in small towns and villages in 5 mostly rural districts (cazas) in Lebanon. These rural cazas were selected for their particular sociocultural characteristics: Akkar and Batroun in north Lebanon, Chouf in the central Mount Lebanon area, Sour (Tyre) in south Lebanon and Zahleh in the eastern inner Bekaa valley.

\section{Sampling procedures}

The selection of participants was performed using a cluster sampling technique. Blocks were randomly selected from detailed maps, and buildings selected from within those blocks. Interviewers then went to those buildings ("cluster units") and canvassed women door-to-door. Questionnaires were completed with consenting women who fitted the inclusion criteria: age $40+$ years (in surveys S1 and S2) or age 35+ years (in surveys S3-S5) and residing permanently in the area for more than 1 year.

Selected clusters were canvassed consecutively until the target number of respondents was obtained. These procedures were systematically applied in all waves, and in all locations, including Beirut and suburbs after 2004.

\section{Instruments}

A structured questionnaire was developed and tested. It included several sociodemographic questions in addition to questions regarding women's perceptions about breast cancer, the advantages of and obstacles to obtaining a mammography, and reactions to various components of the campaign. A preliminary survey using this questionnaire was conducted for survey S1, prior to the campaign of 2003, among 1200 women selected in the same areas and in the same manner described above. Experience acquired in that preliminary survey was used as a pilot test to improve the flow and clarity of the questionnaire.

At the time of the visit, the aim of the survey was explained to the eligible woman, and her free verbal consent to participate was obtained. When a woman refused to participate, interviewers moved on to her neighbours in the next household within the same cluster unit. The questionnaire was completed in a face-to-face interview conducted with the woman at home, in the mornings and afternoons. Slight changes were introduced in later waves in light of experience acquired in the field and evolving action research questions. 


\section{Statistical analysis}

In this descriptive analysis, all categorical variables were tabulated as frequencies and percentages and continuous variables as means, standard deviations (SD) and ranges. Prevalence rates were presented with their $95 \%$ confidence intervals $(\mathrm{CI})$ :

The total prevalence was not weighted in proportion to the regional components, to avoid the impression that this may be a "national" prevalence figure. Indeed, this could have been possible had the sampling extended to the entire national territory. However, for the purpose of this action research evaluation analysis, an expertdetermined sampling of specific areas was judged sufficient. Nevertheless, in view of the large proportion of the population which actually lives in the sampled areas, it is very likely that total prevalence rates found here are good estimates of the national figure. On the other hand, the validity of findings within each region is much more solid, as sampling within areas was conducted using a strict cluster random technique.

Comparisons of specific outcomes such as mammography utilization were performed by region and age group. These were tested using the Student $t$-test and its derivatives, chi-squared, Fisher exact test or $z$-test, depending on the situation. Comparisons with $P$-value $\leq 0.05$ were considered statistically significant. All analyses were conducted using SPSS-PC, complemented when needed by the Stat-Calc function of Epi-Info, version 6.

\section{Results}

\section{Sociodemographic characteristics}

The first 2 surveys were conducted with 1200 women drawn from 5 rural areas not contiguous with greater Beirut. Starting with S3, the same total sample was selected from those districts as well as from Beirut city and suburbs. In S1, the mean age of the group was 50 (SD 11) years, range 40-87 years (Table 1). The mean age at menarche was 13.1 (SD 1.5) years. The mean age at marriage was 20 (SD 5) years, range 9-49 years. The mean number of children was 4.1 (SD 2.8), range 0-22. The mean crowding index, an indicator of socioeconomic status (SES) [5], was 1.9 (SD 1.4) persons/room in the family household, range $0.17-13$. A level of crowding of 1 person/room is generally considered as indicating middle class SES; higher levels are associated with lower SES. The skewed distribution of the crowding index prompted us to consider using the median instead of the mean in all later considerations of this variable. When medians are considered, the selected groups at each wave and in each region tended towards the middle-class level of 1 person/ room. Of surveyed women, only $20 \%$ had employment outside the home.

The 1200 women participating in the second survey (S2) did not differ on most sociodemographic variables from those surveyed in S1. The proportion of working women rose to $26 \%$, which may have improved the median crowding index, which fell to 1.2 , indicating better SES. The mean age of participants, age at menarche, age at first marriage and number of children did not vary in a significant way in any subsequent wave. The inclusion of women from greater Beirut resulted in an increase in the proportion of working women, with a concomitant lowering of the crowding index.

\section{Mammography utilization}

The proportion of women who had obtained a mammography in the previous 12 months varied between areas, and between years (Table 2). Few consistent trends were 


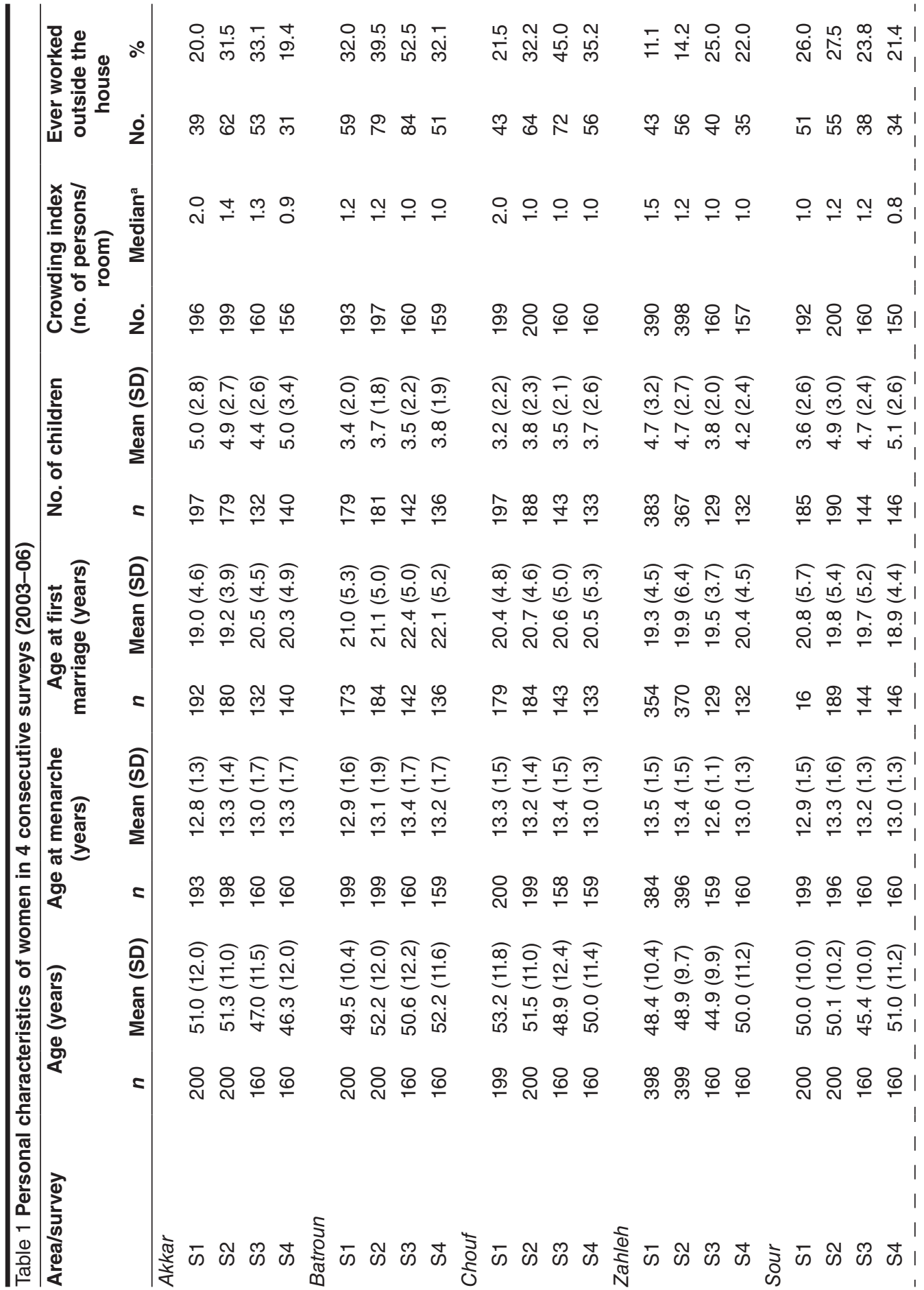

المجلة الصحية لشرق المتوسط، منظمة الصحة العالمية، المجلد الخامس عشر، العدد (، 9 ·. 
detected. Overall, the prevalence of utilization increased between surveys S1 and S4, but such a trend may be largely attributable to the inclusion of subgroups from Beirut city and suburbs. Detailed comparisons in surveys S3 and S4 indicated that the rate of mammography use among women in greater Beirut was almost twice as high as among women from outside. In most cases, utilization results fluctuated, except for the Chouf area where they remained relatively low (about 10\%) across all 4 waves. In survey S2, utilization was the lowest in the Zahleh, Sour and Chouf districts (9\% to $10 \%$ ). It was $22 \%$ in the Batroun area, and was the highest (29\%) in Akkar. In contrast, in survey S4, utilization was lowest in Akkar (6\%). It was $12 \%$ in Chouf, $16 \%$ in Zahleh and Sour and 20\% in Batroun. The highest levels were noted in Beirut city and suburbs $(25 \%)$.

At all waves, among women who had done a mammography in the previous 12 months, a large proportion had obtained it for the first time in their life (Table 2). The proportions ranged from a low of $43.6 \%$ (survey S3) to a high of $66.7 \%$ (survey S4). No data were obtained from survey S1. Increasing trends for first-ever utilization could be found over time in almost all areas surveyed. The proportion of first-time users was consistently higher among women in the regions compared to those from Beirut city and suburbs (Table 2).

\section{Mammography utilization by age}

At any single wave, utilization was low, but less so among women aged 40-59 years than among younger or older ones. In particular, in survey S4, significantly lower rates of utilization were found among women aged $<35$ years $(12.4 \%)$ or $60+$ years $(11.4 \%)$, while significantly higher proportions were found among women aged $40-49$ years $(21.8 \%)$ and $50-59$ years $(21.5 \%)$. No other trends 
Table 2 Utilization of mammography in the previous 12 months in 4 consecutive surveys and first ever utilization in 3 consecutive surveys among Lebanese women

\begin{tabular}{|c|c|c|c|c|c|c|}
\hline \multirow[t]{2}{*}{ Area/survey } & \multicolumn{3}{|c|}{$\begin{array}{l}\text { Utilization of mammography in } \\
\text { previous } 12 \text { months }\end{array}$} & \multicolumn{3}{|c|}{$\begin{array}{c}\text { First ever utilization of } \\
\text { mammography }\end{array}$} \\
\hline & $\mathrm{n} / \mathrm{N}$ & $\%(95 \% \mathrm{Cl})^{\mathrm{a}}$ & $P$-value ${ }^{b}$ & $\mathrm{n} / \mathrm{N}$ & $\%(95 \% \mathrm{Cl})^{\mathrm{a}}$ & $P$-value ${ }^{b}$ \\
\hline \multicolumn{7}{|c|}{ Outside Beirut } \\
\hline \multicolumn{7}{|c|}{ Akkar } \\
\hline S1 & $21 / 200$ & $10.5(6.3-14.7)$ & 0.655 & $\mathrm{n} / \mathrm{a}$ & $\mathrm{n} / \mathrm{a}$ & - \\
\hline S2 & $58 / 200$ & $29.0(22.7-35.3)$ & $<0.001$ & $34 / 56$ & 60.7 (47.9-73.5) & 0.363 \\
\hline S3 & $22 / 160$ & $13.8(8.4-19.1)$ & 0.12 & $13 / 22$ & $59.1(38.5-79.6)$ & 0.122 \\
\hline S4 & $10 / 160$ & $6.3(2.5-10.0)$ & $<0.001$ & $8 / 10$ & $80.0(55.2-100)$ & 0.316 \\
\hline \multicolumn{7}{|l|}{ Batroun } \\
\hline S1 & $26 / 200$ & $13.0(8.3-17.7)$ & 0.44 & $\mathrm{n} / \mathrm{a}$ & $\mathrm{n} / \mathrm{a}$ & - \\
\hline $\mathrm{S} 2$ & $44 / 200$ & $22.0(16.3-27.7)$ & 0.001 & $20 / 44$ & $45.5(30.7-60.2)$ & 0.112 \\
\hline S3 & $23 / 160$ & $14.4(8.9-19.8)$ & 0.181 & $15 / 23$ & $65.2(45.7-84.7)$ & 0.027 \\
\hline S4 & $32 / 160$ & 20.0 (13.8-26.2) & $<0.424$ & $22 / 32$ & $68.8(52.7-84.8)$ & 0.882 \\
\hline \multicolumn{7}{|l|}{ Chouf } \\
\hline S1 & $20 / 200$ & $10.0(5.8-14.2)$ & 0.49 & $\mathrm{n} / \mathrm{a}$ & $\mathrm{n} / \mathrm{a}$ & - \\
\hline $\mathrm{S} 2$ & $20 / 200$ & $10.0(5.8-14.2)$ & 0.038 & $11 / 20$ & $55.0(33.2-76.8)$ & 0.894 \\
\hline S3 & $17 / 160$ & $10.6(5.8-15.4)$ & 0.008 & $8 / 17$ & $47.1(23.3-70.8)$ & 0.763 \\
\hline S4 & $19 / 160$ & $11.9(6.9-16.9)$ & 0.0367 & $12 / 19$ & $63.2(41.5-84.8)$ & 0.663 \\
\hline \multicolumn{7}{|l|}{ Zahleh } \\
\hline S1 & $31 / 400$ & $7.8(5.1-10.3)$ & 0.005 & $\mathrm{n} / \mathrm{a}$ & $\mathrm{n} / \mathrm{a}$ & - \\
\hline S2 & $37 / 400$ & $9.3(6.4-12.1)$ & $<0.001$ & $22 / 37$ & $59.5(43.6-75.3)$ & 0.608 \\
\hline S3 & $30 / 160$ & $18.8(12.7-24.8)$ & 0.279 & $9 / 30$ & $30.0(13.6-46.4)$ & 0.106 \\
\hline S4 & $26 / 160$ & $16.3(10.5-22.0)$ & 0.594 & $21 / 26$ & $80.8(65.6-95.9)$ & 0.126 \\
\hline \multicolumn{7}{|l|}{ Sour } \\
\hline S1 & $38 / 200$ & $19.0(13.6-24.4)$ & $<0.001$ & $\mathrm{n} / \mathrm{a}$ & $\mathrm{n} / \mathrm{a}$ & - \\
\hline $\mathrm{S} 2$ & $18 / 200$ & $9.0(5.0-13.0)$ & 0.012 & $10 / 17$ & $58.8(35.4-82.2)$ & 0.788 \\
\hline S3 & $19 / 160$ & $11.9(6.9-16.9)$ & 0.027 & $13 / 19$ & 68.4 (47.5-89.3) & 0.022 \\
\hline S4 & $26 / 160$ & $16.3(10.5-22.0)$ & 0.594 & $20 / 25$ & $80.0(64.3-95.7)$ & 0.159 \\
\hline \multicolumn{7}{|l|}{ Total } \\
\hline S1 & $136 / 1200$ & $11.3(9.5-13.1)$ & - & $\mathrm{n} / \mathrm{a}$ & $\mathrm{n} / \mathrm{a}$ & - \\
\hline $\mathrm{S} 2$ & $177 / 1200$ & $14.8(12.7-16.8)$ & - & $97 / 174$ & $55.7(48.4-63.1)$ & - \\
\hline S3 & $111 / 1200$ & $13.9(11.5-16.3)$ & $<0.001$ & $58 / 111$ & $62.3(43.0-61.5)$ & 0.009 \\
\hline S4 & $113 / 1200$ & $14.1(11.7-16.5)$ & $<0.001$ & $83 / 112$ & $74.1(66.0-82.2)$ & 0.032 \\
\hline \multicolumn{7}{|c|}{ Greater Beirut } \\
\hline \multicolumn{7}{|c|}{ Beirut city } \\
\hline S1 & $\mathrm{n} / \mathrm{a}$ & $\mathrm{n} / \mathrm{a}$ & - & $\mathrm{n} / \mathrm{a}$ & $\mathrm{n} / \mathrm{a}$ & - \\
\hline S2 & $\mathrm{n} / \mathrm{a}$ & $\mathrm{n} / \mathrm{a}$ & - & $\mathrm{n} / \mathrm{a}$ & $\mathrm{n} / \mathrm{a}$ & - \\
\hline S3 & $51 / 200$ & 25.5 (19.5-31.5) & $<0.003$ & $17 / 51$ & $33.3(20.4-46.3)$ & 0.092 \\
\hline S4 & $51 / 200$ & $25.5(19.5-31.5)$ & 0.002 & $24 / 50$ & $48.0(34.1-61.8)$ & $<0.001$ \\
\hline
\end{tabular}


Table 2 Utilization of mammography in the previous 12 months in 4 consecutive surveys and first ever utilization in 3 consecutive surveys among Lebanese women (concluded)

\begin{tabular}{|c|c|c|c|c|c|c|}
\hline \multirow[t]{2}{*}{ Area/survey } & \multicolumn{3}{|c|}{$\begin{array}{l}\text { Utilization of mammography in } \\
\text { previous } 12 \text { months }\end{array}$} & \multicolumn{3}{|c|}{$\begin{array}{l}\text { First ever utilization of } \\
\text { mammography }\end{array}$} \\
\hline & $\mathrm{n} / \mathrm{N}$ & $\%(95 \% \mathrm{Cl})^{\mathrm{a}}$ & $P$-value ${ }^{b}$ & $\mathrm{n} / \mathrm{N}$ & $\%(95 \% \mathrm{Cl})^{\mathrm{a}}$ & $P$-value ${ }^{b}$ \\
\hline \multicolumn{7}{|c|}{ Beirut suburbs } \\
\hline S1 & $\mathrm{n} / \mathrm{a}$ & $\mathrm{n} / \mathrm{a}$ & - & $\mathrm{n} / \mathrm{a}$ & $\mathrm{n} / \mathrm{a}$ & - \\
\hline S2 & $\mathrm{n} / \mathrm{a}$ & $\mathrm{n} / \mathrm{a}$ & - & $\mathrm{n} / \mathrm{a}$ & $\mathrm{n} / \mathrm{a}$ & - \\
\hline S3 & $56 / 200$ & $28.0(21.8-34.2)$ & $<0.001$ & $20 / 56$ & 35.7 (23.2-48.3) & 0.169 \\
\hline S4 & $49 / 200$ & $24.5(18.5-30.5)$ & 0.006 & $35 / 48$ & $72.9(60.3-85.5)$ & 0.372 \\
\hline \multicolumn{7}{|l|}{ Total } \\
\hline S1 & $\mathrm{n} / \mathrm{a}$ & $\mathrm{n} / \mathrm{a}$ & - & $\mathrm{n} / \mathrm{a}$ & $\mathrm{n} / \mathrm{a}$ & - \\
\hline S2 & $\mathrm{n} / \mathrm{a}$ & $\mathrm{n} / \mathrm{a}$ & - & $\mathrm{n} / \mathrm{a}$ & $\mathrm{n} / \mathrm{a}$ & - \\
\hline S3 & $107 / 400$ & $26.8(22.4-31.1)$ & $<0.001$ & $37 / 107$ & $34.6(25.6-43.6)$ & 0.009 \\
\hline S4 & $100 / 400$ & $25.0(20.8-29.2)$ & $<0.001$ & $59 / 98$ & $60.2(50.5-69.9)$ & 0.032 \\
\hline \multicolumn{7}{|l|}{ All areas } \\
\hline S1 & $136 / 1200$ & $11.3(9.5-13.1)$ & - & $\mathrm{n} / \mathrm{a}$ & $\mathrm{n} / \mathrm{a}$ & - \\
\hline $\mathrm{S} 2$ & $177 / 1200$ & $14.8(12.7-16.8)$ & - & $97 / 174$ & $55.7(47.6-62.4)$ & - \\
\hline S3 & $218 / 1200$ & $18.2(16.0-20.3)$ & - & $95 / 218$ & $43.6(37.0-50.2)$ & - \\
\hline S4 & $213 / 1200$ & $17.8(15.6-19.9)$ & - & $142 / 210$ & $67.6(61.3-73.9)$ & - \\
\hline
\end{tabular}

${ }^{a}$ Percentage of women who had a mammography in the previous year, with corresponding $95 \%$ confidence interval.

${ }^{b}$ Obtained from a z-test or Fisher exact test comparing the prevalence in 1 group to the prevalence in all others combined, or the prevalence outside Beirut compared to the prevalence in Greater Beirut.

S1 = September 2003 survey; S2 = January 2004 survey; S3 = January 2005 survey; S4 = January 2006 survey. $n / N=$ no. of women /total no. of women sampled; $n / a=$ no samples taken.

existed across waves (Table 3). As expected, the proportion of first-time users among women who obtained a mammography in the past 12 months decreased with older age groups. This trend was consistent across the 3 waves in which this variable was assessed (Table 3).

\section{Overall impact of breast cancer awareness campaigns}

The overall impact of the campaigns has been measured since survey S3 (Table 4). Overall, more than $50 \%$ of participants mentioned that they had heard about the ongoing campaign at each given time. In all areas, the proportion of women who had heard of the breast cancer awareness campaigns increased consistently between surveys S3 and S4, except in Akkar. The impact was highest in Beirut city and suburbs. In the suburbs, the proportion in survey S3 was already relatively high $(69 \%)$ and thus could improve by only a small fraction to $70 \%$.

Given that they had heard about the campaign, the proportion of women who were actually prompted to action was relatively low. While increasing in total from surveys S3 to S4 (9.7\% and $14.3 \%$ respectively), those figures did not increase in Beirut city and suburbs (Table 4). In fact between surveys S3 and S4, the proportion of women prompted to action in Beirut city decreased from $22 \%$ to $19 \%$, and in the suburbs from about $14 \%$ to $12 \%$. Further analysis in surveys $\mathrm{S} 3$ and $\mathrm{S} 4$ confirmed the

المجلة الصحية لشرق المتوسط، منظمة الصحة العالمية، المجلد الخامس عشر، العدد (، 9. ب 


\begin{tabular}{|c|c|c|c|c|c|c|}
\hline \multirow[t]{2}{*}{$\begin{array}{l}\text { Age group/ } \\
\text { survey }\end{array}$} & \multicolumn{3}{|c|}{$\begin{array}{l}\text { Utilization of mammography in } \\
\text { previous } 12 \text { months }\end{array}$} & \multicolumn{3}{|c|}{$\begin{array}{l}\text { First ever utilization of } \\
\text { mammography }\end{array}$} \\
\hline & $n / N$ & $\%(95 \% \mathrm{Cl})^{\mathrm{a}}$ & $P$-value ${ }^{b}$ & $n / N$ & $\%(95 \% \mathrm{Cl})^{\mathrm{a}}$ & $P$-value ${ }^{b}$ \\
\hline \multicolumn{7}{|l|}{$<40$ years } \\
\hline S1 & $\mathrm{n} / \mathrm{a}$ & $\mathrm{n} / \mathrm{a}$ & $\mathrm{n} / \mathrm{a}$ & $\mathrm{n} / \mathrm{a}$ & $\mathrm{n} / \mathrm{a}$ & - \\
\hline S2 & $\mathrm{n} / \mathrm{a}$ & $\mathrm{n} / \mathrm{a}$ & $\mathrm{n} / \mathrm{a}$ & $\mathrm{n} / \mathrm{a}$ & $\mathrm{n} / \mathrm{a}$ & $\mathrm{n} / \mathrm{a}$ \\
\hline S3 & 33/329 & $10.0(6.8-13.3)$ & $<0.001$ & $22 / 33$ & $66.7(50.6-82.8)$ & 0.018 \\
\hline S4 & $25 / 202$ & $12.5(7.6-17.3)$ & 0.028 & $21 / 25$ & $84.0(69.6-98.4)$ & 0.062 \\
\hline \multicolumn{7}{|l|}{ 40-49 years } \\
\hline S1 & $77 / 713$ & $10.8(8.5-13.1)$ & 0.394 & $\mathrm{n} / \mathrm{a}$ & $\mathrm{n} / \mathrm{a}$ & - \\
\hline S2 & $99 / 663$ & $14.9(12.2-17.6)$ & 0.885 & $58 / 96$ & $60.4(50.6-70.2)$ & 0.198 \\
\hline S3 & $85 / 420$ & $20.2(16.4-24.1)$ & 0.172 & $37 / 85$ & $43.5(33.0-54.1)$ & 0.991 \\
\hline S4 & $96 / 441$ & $21.8(17.9-25.6)$ & 0.005 & $69 / 93$ & $74.2(65.3-83.1)$ & 0.069 \\
\hline \multicolumn{7}{|l|}{ 50-59 years } \\
\hline $\mathrm{S} 1$ & $31 / 208$ & $14.9(10.1-19.7)$ & 0.085 & $\mathrm{n} / \mathrm{a}$ & $\mathrm{n} / \mathrm{a}$ & - \\
\hline S2 & $46 / 283$ & $16.2(12.0-20.5)$ & 0.418 & $24 / 45$ & $53.3(38.8-67.9)$ & 0.705 \\
\hline S3 & $51 / 210$ & $24.3(18.5-30.1)$ & 0.011 & $21 / 51$ & $41.2(27.7-54.7)$ & 0.693 \\
\hline S4 & $61 / 284$ & $21.5(16.7-26.2)$ & 0.06 & $35 / 61$ & $57.4(45.0-69.8)$ & 0.042 \\
\hline \multicolumn{7}{|l|}{$\geq 60$ years } \\
\hline S1 & 29/276 & $10.5(6.9-14.1)$ & 0.577 & $\mathrm{n} / \mathrm{a}$ & $\mathrm{n} / \mathrm{a}$ & - \\
\hline S2 & $32 / 250$ & $12.8(8.7-16.9)$ & 0.325 & $15 / 32$ & $46.9(29.6-64.2)$ & 0.263 \\
\hline S3 & $49 / 241$ & $20.3(15.2-25.4)$ & 0.329 & $15 / 49$ & $30.6(17.7-43.5)$ & 0.038 \\
\hline S4 & $31 / 273$ & $11.3(7.6-15.1)$ & 0.002 & $17 / 31$ & $54.8(37.3-72.4)$ & 0.099 \\
\hline \multicolumn{7}{|l|}{ All ages } \\
\hline S1 & $137 / 1197$ & $11.4(9.6-13.2)$ & - & $\mathrm{n} / \mathrm{a}$ & $\mathrm{n} / \mathrm{a}$ & - \\
\hline $\mathrm{S} 2$ & $177 / 1196$ & $14.8(12.8-16.8)$ & - & $97 / 173$ & $56.1(48.7-63.5)$ & - \\
\hline S3 & 218/1200 & $18.2(16.0-20.3)$ & - & $95 / 218$ & $43.6(37.0-50.2)$ & - \\
\hline S4 & $213 / 1200$ & $17.8(15.6-19.9)$ & - & $142 / 210$ & $67.6(61.3-74.0)$ & - \\
\hline
\end{tabular}

aPercentage of women who had a mammography in the previous year, with corresponding $95 \%$ confidence interval $(95 \% \mathrm{Cl})$

${ }^{b}$ Obtained from a z-test or Fisher exact test, depending on the situation, comparing the prevalence in 1 group to the prevalence in all others combined.

S1 = September 2003 survey; S2 = January 2004 survey; S3 = January 2005 survey; S4 = January 2006 survey. n/a $=$ no sample taken.

impression that the proportion of women who had heard of the campaigns was significantly higher in greater Beirut than in other regions. Changes have been found regarding the effect of those campaigns in prompting action. The difference between greater Beirut and other regions vastly decreased between surveys S3 and S4.

\section{Discussion}

Annual national campaigns in Lebanon, usually held in October, have been promoting the utilization of mammography to screen for breast cancer among women aged $40+$ years. There are no readily available data concerning mammography utilization 
Table 4 Overall impact of breast cancer awareness campaigns among Lebanese women in 2 consecutives surveys

\begin{tabular}{|c|c|c|c|c|c|c|}
\hline \multirow[t]{2}{*}{ Area/survey } & \multicolumn{3}{|c|}{$\begin{array}{l}\text { Heard about last breast } \\
\text { cancer campaign }\end{array}$} & \multicolumn{3}{|c|}{$\begin{array}{c}\text { Heard about last breast cancer } \\
\text { campaign and had a } \\
\text { mammography as a result }\end{array}$} \\
\hline & $\mathrm{n} / \mathrm{N}$ & $\%$ & $P$-value ${ }^{a}$ & $\mathrm{n} / \mathrm{N}$ & $\%$ & $P$-value ${ }^{a}$ \\
\hline \multicolumn{7}{|c|}{ Outside Beirut } \\
\hline \multicolumn{7}{|c|}{ Akkar } \\
\hline S3 & $87 / 160$ & 54.4 & 0.347 & $6 / 87$ & 6.9 & 0.347 \\
\hline S4 & $70 / 160$ & 43.8 & $<0.001$ & $10 / 64$ & 15.6 & 0.705 \\
\hline \multicolumn{7}{|l|}{ Batroun } \\
\hline S3 & $77 / 160$ & 48.1 & 0.448 & $2 / 77$ & 2.6 & 0.025 \\
\hline $\mathrm{S} 4$ & $105 / 160$ & 65.6 & 0.275 & $10 / 105$ & 9.5 & 0.319 \\
\hline \multicolumn{7}{|l|}{ Chouf } \\
\hline S3 & $74 / 160$ & 46.3 & 0.205 & $3 / 74$ & 4.1 & 0.082 \\
\hline S4 & $84 / 160$ & 52.5 & 0.01 & $11 / 83$ & 13.3 & 0.824 \\
\hline \multicolumn{7}{|l|}{ Zahleh } \\
\hline S3 & $61 / 160$ & 38.1 & $<0.001$ & $3 / 61$ & 4.9 & 0.081 \\
\hline S4 & $97 / 160$ & 60.6 & 0.76 & $15 / 96$ & 15.6 & 0.635 \\
\hline \multicolumn{7}{|l|}{ Sour } \\
\hline S3 & $61 / 160$ & 38.1 & $<0.001$ & $1 / 61$ & 1.6 & 0.025 \\
\hline S4 & $84 / 160$ & 52.5 & 0.01 & $11 / 81$ & 13.6 & 0.896 \\
\hline \multicolumn{7}{|l|}{ Total } \\
\hline S3 & $360 / 800$ & 45.0 & $<0.001$ & $15 / 360$ & 4.2 & $<0.001$ \\
\hline S4 & $440 / 800$ & 55.0 & $<0.001$ & $57 / 429$ & 13.3 & 0.356 \\
\hline \multicolumn{7}{|l|}{ Greater Beirut } \\
\hline \multicolumn{7}{|l|}{ Beirut city } \\
\hline S3 & $113 / 200$ & 56.5 & 0.084 & $25 / 113$ & 22.1 & $<0.001$ \\
\hline S4 & $159 / 199$ & 79.9 & $<0.001$ & $30 / 159$ & 18.9 & 0.049 \\
\hline \multicolumn{7}{|l|}{ Beirut suburbs } \\
\hline S3 & $138 / 200$ & 69.0 & $<0.001$ & $19 / 138$ & 13.8 & 0.063 \\
\hline S4 & $141 / 200$ & 70.1 & 0.005 & $17 / 140$ & 12.1 & 0.47 \\
\hline \multicolumn{7}{|l|}{ Total } \\
\hline S3 & $251 / 400$ & 62.8 & $<0.001$ & $44 / 251$ & 17.5 & $<0.001$ \\
\hline S4 & $300 / 399$ & 75.2 & $<0.001$ & $47 / 299$ & 15.7 & 0.356 \\
\hline \multicolumn{7}{|l|}{ All areas } \\
\hline S3 & $611 / 1200$ & 51.0 & - & $59 / 611$ & 9.7 & - \\
\hline $\mathrm{S} 4$ & $740 / 1199$ & 61.7 & - & $104 / 740$ & 14.3 & - \\
\hline
\end{tabular}

${ }^{a}$ Obtained from a z-test or Fisher exact test, depending on the situation, comparing the prevalence in 1 group to the prevalence in all others combined.

S3 = January 2005 survey; S4 = January 2006 survey.

$n / N=$ no. of women/total no. of women sampled. 
in Lebanon and the Arab world. A key indicator for success of such campaigns is the percentage of those who underwent a mammogram within an interval recommended by professional organizations. Data collected from 1200 women with a mean age of 50 years, across various regions of Lebanon, from 4 consecutive surveys assessing the awareness campaigns between 2003 and 2005, indicated that the proportion of "proper" utilization within the previous 12 months was low and increased only slightly over time ( $11 \%$ to $18 \%)$.

Prior to our study, only 1 report could be located in Lebanon [unpublished report, Hariri Foundation, 2001]. It involved 315 women of the same average age, surveyed in Beirut and Saida in 2001. That report found an even lower proportion of mammography utilization (7\%) within the previous 12 months. These figures may indicate that progress in awareness and utilization may be occurring in Lebanon, even if at a very slow pace, and with regional and age differences. This progress can be largely attributed to the national October campaigns which remain the only concerted effort conducted in Lebanon on the issue of breast cancer. The campaigns are actually acting as triggers for activities implemented by various nongovernmental organizations throughout the year to promote mammography and facilitate obtaining it in various subpopulations of women in Lebanon.

The rate of recent mammography utilization is definitely higher in more developed nations, around $70 \%$ in the United States $[6,7]$ and France $[8,9]$. On the other hand, Lebanese rates are nearer to those in developing nations. In Istanbul, Turkey, a country socioeconomically and sociologically comparable to Lebanon, the rate of undergoing a recommended mammography in 2003 was 12.6\% [10]. As prevention and awareness efforts are repeated and improved, and ob- stacles defined and removed, we can hope that utilization rates will improve to equal those of more developed nations.

It is most important that women in the age group 40-60 years abide by recommendations for an annual breast mammography. This is the age group likely to benefit the most from screening, and in whom mammography is systematically recommended in Lebanon and elsewhere. Studies have shown that screening mammography in women in this age group decreased mortality by about $20 \%-35 \%$ [11]. It was reassuring to find that, in all waves, mammography utilization in women aged 40-60 years was almost twice as high as in both younger and older women. Nevertheless, messages should be clearly sent to women with a family history of breast cancer to start having a mammogm as early as 35 years [12]. With increasing life expectancy in Lebanon, as elsewhere, more women will be reaching the $60+$ years age group. They will be expected to live a healthy life and cannot be neglected as potential beneficiaries of breast cancer screening [13].

Repeat mammography is also an important indicator for the greatest populationlevel benefits on breast cancer morbidity and mortality [14]. In the first survey (S1) only $2.2 \%$ of women said they had had more than 1 mammogram in the past. This rate is negligible compared with the rate of $25 \%$ in Turkey [15] and $40 \%$ in the Umited States of America in the same period [16]. The existence of fluctuations in repeat mammography across all years and within regions may be attributed to a false sense of security acquired from a first "normal" mammogram, which then acts as a disincentive to obtaining another one in the absence of any perceived breast changes. Therefore, campaigns should clearly indicate the need for repeating the test even if the results were negative in the previous year. Starting with 
the 2007 campaign, advertisements have emphasized this point consistently.

Overall, the campaigns were less effective in the regions outside greater Beirut and their prompting effect was lower. Rates of adequate utilization were also lower. However, not all regions were equally affected. Those with larger rural populations such as Chouf and Akkar had worse indicators than areas with some urban centres such as Zahleh and Sour. This seems to indicate that obtaining a mammography in some areas may be hampered by logistic obstacles such as availability, affordability and access. Other negative factors may be related to values, expectations and beliefs of women in various regions of Lebanon. Those issues are currently under investigation using data collected in the same surveys.

In conclusion, the breast cancer campaigns focusing on the importance of annual screening mammography are having a small yet measurable impact on women's practice in Lebanon. While progress is expected to remain slow for several years, it has to be sustained until a critical mass of women has acquired the regular habit and annual mammography has become the norm in Lebanon. It is hoped that publishing such data may prompt similar efforts to initiate screening campaigns in other parts of the Arab world where breast cancer is on the rise.

\section{Acknowledgements}

The activities of the National Breast Cancer Awareness Campaigns are conducted under the umbrella of the Ministry of Public Health in Lebanon, and largely funded through grants from Roche International. The survey data collection and entry was conducted by Statistics Lebanon, a private survey company in Beirut.

\section{References}

1. Abou-Daoud KT. Morbidity from cancer in Lebanon. Cancer, 1966, 19(9):1293300.

2. Adib SM et al. Cancer in Lebanon: an epidemiological review of the American University of Beirut Medical Center Tumor Registry (1983-1994). Annals of epidemiology, 1998, 8(1):46-51.

3. Shamseddine A et al. Cancer incidence in post-war Lebanon: findings from the First National Population-based Registry, 1998. Annals of epidemiology, 2004, 14(9):663-8.

4. Cancer in Lebanon 2003. Beirut, National Cancer Registry, 2006 (www.leb.emro. who.int/NCR2003.pdf, accessed 12 September 2008).

5. Melki IS et al. Household crowding index: a correlate of socio-economic status and inter-pregnancy spacing in an urban set- ting. Journal of epidemiology and community health, 2004, 58(6):476-80.

6. Breen $\mathrm{N}$ et al. Progress in cancer screening over a decade: Results of cancer screening from the 1987, 1992, $1998 \mathrm{Na}-$ tional Health Interview Surveys. Journal of the National Cancer Institute, 2001, 93(22):1704-13.

7. Swan J et al. Progress in cancer screening practices in the United States: results from the 2000 National Health Interview Survey. Cancer, 2003, 97(6):1528-40.

8. Guilbert P, Baudier F, Gautier A. Baromètre Santé 2000. Volume 2. Résultats [Health barometer 2000. Volume 2. Outcomes]. Vanves, Comité Français d'Education pour la Santé, 2001.

9. Duport N, Ancelle-Park R. Do sociodemographic factors influence mammography use of French women? Analysis of 
a French cross-sectional survey. European journal of cancer prevention, 2006, 15(3):219-24.

10. Secginli S, Nahcivan N. Breast cancer screening behaviors among women. Proceedings of the 2nd International and 9th National Nursing Congress, 7-11 September 2003. Antalya, Turkey, 2003.

11. Elmore JG et al. Screening for breast cancer. Journal of the American Medical Association, 2005, 293(10):1245-56.

12. Johnson ET. Breast cancer racial differences before age 40-implications for screening. Journal of the National Medical Association, 2002, 94(3):149-56.

13. Walter LC, Lewis CL, Barton MB. Screening for colorectal, breast, and cervical cancer in the elderly: a review of the evidence. American journal of medicine, 2005, 118(10):1078-86.

14. Smith RA et al. American Cancer Society guidelines for breast cancer screening: update 2003. CA: a cancer journal for clinicians, 2003, 53(3):141-69.

15. Secginli S, Nahcivan NO. Factors associated with breast cancer screening behaviours in a sample of Turkish women: a questionnaire survey. International journal of nursing studies, 2006, 43(2):161-71.

16. Glass $A G$ et al. Breast cancer incidence 1980-2006: combined roles of menopausal hormone therapy, screening mammography and estrogen receptor status. Journal of the National Cancer Institute, 2007, 99(15):1152-61.

\section{Correction}

Knowledge of and attitudes towards HIV/AIDS in Mashhad, Islamic Republic of Iran by M.R. HedayatiMoghaddam. Eastern Mediterranean Health Journal, 2008, 14(6):1321-32. The affiliation should read: Research Centre for HIV/AIDS \& Viral Hepatitis, Iranian Academic Centre for Education, Culture \& Research (ACECR), Mashhad Branch, Ferdowsi University Campus, Mashhad, Islamic Republic of Iran. On page 1324, Results section, paragraph 1, last line, the correct phrase is: almost half (49.9\%) (not $49.5 \%$ ) had high school education. 